OPEN ACCESS

Edited by:

Josef Kittler

University College London, UK

Reviewed by:

Daniele Bottai,

University of Milan, Italy

Jacek Jaworski,

International Institute of Molecular and

Cell Biology, Poland

*Correspondence:

Anne Biever

anne.biever@igf.cnrs.fr:

Emma Puighermanal

emma.puighermana/@igf.cnrs.fr

Received: 02 October 2015 Accepted: 23 November 2015 Published: 16 December 2015

Citation:

Biever $A$, Valjent $E$ and Puighermanal E (2015) Ribosomal Protein S6 Phosphorylation in the Nervous System: From Regulation to Function. Front. Mol. Neurosci. 8:75. doi: 10.3389/fnmol.2015.00075

\section{Ribosomal Protein S6 Phosphorylation in the Nervous System: From Regulation to Function}

\author{
Anne Biever ${ }^{1,2,3 *}$, Emmanuel Valjent ${ }^{1,2,3}$ and Emma Puighermanal ${ }^{1,2,3 *}$ \\ ${ }^{1}$ Centre National de la Recherche Scientifique, UMR5203, Institut de Génomique Fonctionnelle, Montpellier, France, ${ }^{2}$ Institut \\ National de la Santé et de la Recherche Médicale, U1191, Montpellier, France, ${ }^{3}$ Université de Montpellier, UMR-5203, \\ Montpellier, France
}

Since the discovery of the phosphorylation of the 40S ribosomal protein S6 (rpS6) about four decades ago, much effort has been made to uncover the molecular mechanisms underlying the regulation of this post-translational modification. In the field of neuroscience, rpS6 phosphorylation is commonly used as a readout of the mammalian target of rapamycin complex 1 signaling activation or as a marker for neuronal activity. Nevertheless, its biological role in neurons still remains puzzling. Here we review the pharmacological and physiological stimuli regulating this modification in the nervous system as well as the pathways that transduce these signals into rpS6 phosphorylation. Altered rpS6 phosphorylation observed in various genetic and pathophysiological mouse models is also discussed. Finally, we examine the current state of knowledge on the physiological role of this post-translational modification and highlight the questions that remain to be addressed.

Keywords: rpS6 phosphorylation, mRNA translation, ribosome, mTOR, S6K, PP-1, brain, signaling cascades

\section{INTRODUCTION}

The eukaryotic ribosome is composed of the small $40 \mathrm{~S}$ and the large $60 \mathrm{~S}$ subunits, comprising together 4 ribosomal RNA species and 79 ribosomal proteins (Kressler et al., 2010). In many organisms, ribosomal proteins undergo various post-translational modifications, including phosphorylation, acetylation, methylation, $O$-linked $\beta-N$-acetylglucosaminylation, and ubiquitylation (Xue and Barna, 2012). Historically, the phosphorylation of the 40S ribosomal protein S6 (rpS6) was the first post-translational modification described (Gressner and Wool, 1974). The presence of phospho-rpS6 (p-rpS6) at different levels in a 2D gel provided the first evidence that rpS6 phosphorylation could occur at several residues (Lastick et al., 1977). Ensuing studies identified five evolutionary conserved and clustered carboxy-terminal phospho-sites, which undergo phosphorylation in an ordered manner, beginning with Ser236 and followed sequentially by Ser235, Ser240, Ser244, and Ser247 (Martin-Pérez and Thomas, 1983; Wettenhall et al., 1992; Meyuhas, 2008, 2015). Intriguingly, the exact function of the post-translational modification of this indispensable ribosomal protein remains enigmatic. Despite the large debate regarding its physiological role, rpS6 phosphorylation is commonly used as a marker for neuronal activity and a readout of mammalian target of rapamycin complex 1 (mTORC1) activity (Meyuhas, 2008, 2015; Mahoney et al., 2009; Knight et al., 2012). This review summarizes our current knowledge regarding the molecular mechanisms as well as the variety of stimuli modulating rpS6 phosphorylation in the nervous system. 


\section{REGULATION OF rpS6 PHOSPHORYLATION}

The p70/p85 S6 kinase 1 (S6K1), which is able to catalyze the phosphorylation of rpS6 at all sites, was the first kinase identified (Krieg et al., 1988; Ferrari et al., 1991; Bandi et al., 1993; Meyuhas, 2008, 2015). Further studies described additional protein kinases targeting selectively the Ser235 and Ser236 residues. These include p90 Ribosomal S6 Kinases (RSK1-4) (Roux et al., 2007), Protein Kinase C (House et al., 1987), Protein Kinase A (PKA) (Moore et al., 2009; Valjent et al., 2011; Yano et al., 2014; Biever et al., 2015), Protein Kinase G (Yano et al., 2014), and Death-Associated Protein Kinase (DAPK) (Schumacher et al., 2006) (Figure 1). Although less studied, the residue Ser247 has been identified as a target of Casein Kinase 1 (Hutchinson et al., 2011). Contrasting with the diversity of kinases regulating rpS6 phosphorylation, the dephosphorylation of the five residues is achieved by a single phosphatase: the Protein Phosphatase-1 (PP-1) (Belandia et al., 1994; Hutchinson et al., 2011) (Figure 1). Since the molecular mechanisms regulating rpS6 phosphorylation have been recently extensively reviewed (Meyuhas, 2015), we focus on the contribution of S6K1/2 kinases and the PKA/PP-1 pathway, being the main upstream mechanisms described to regulate $\mathrm{rpS6}$ phosphorylation in the nervous system.

\section{S6K1/2 Pathway}

In mammalian cells, two different genes encode two isoforms of the S6 Kinase, S6K1, and S6K2. S6K1 has cytosolic and nuclear isoforms (p70 S6K1 and p85 S6K1, respectively), whereas both S6K2 isoforms (p54 S6K2 and p56 S6K2) are primarily nuclear (Martin et al., 2001). As demonstrated by the use of S6K1/S6K2 double knockout mice, both isoforms contribute to the regulation of basal and inducible rpS6 phosphorylation at S235/236 and S240/244 sites (Pende et al., 2004; Kroczynska et al., 2009; Chauvin et al., 2014). Different observations were made in

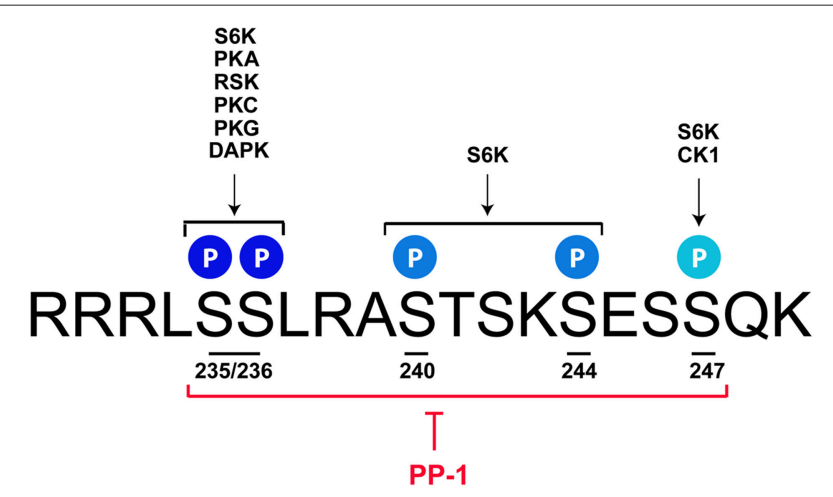

FIGURE 1 | rpS6 phosphorylatable residues are targeted by multiple kinases and dephosphorylated by PP-1. Mus musculus sequence of the C-terminal domain of rpS6 depicting the 5 phosphorylatable sites and their respective kinases. S6K catalyzes the phosphorylation of all the residues, while PKA, RSK, PKC, PKG, and DAPK target the S235 and S236 sites. CK1 selectively phosphorylates the $\mathrm{S} 247$ residue. All phospho-sites are dephosphorylated by PP-1. See text for details. single S6K knockout mice. Indeed, while the S6K2 knockout mice display a reduction of rpS6 phosphorylation only at S235/236 sites in the hippocampus (Antion et al., 2008a), S6K1-deficient mice show no alterations (Antion et al., 2008a; Bhattacharya et al., 2012). Compensatory mechanisms taking place in the single knockout mice could explain these latter observations since viralmediated overexpression of a constitutive-active S6K1 (S6K1 CA) or kinase-inactive S6K1 (S6K1 KI) in the medial prefrontal cortex increases or decreases basal rpS6 phosphorylation, respectively (Dwyer et al., 2015). Pharmacological evidences also support the critical role of $\mathrm{S} 6 \mathrm{~K}$ in the regulation of $\mathrm{rpS} 6$ phosphorylation. S6K1/2 undergo phosphorylation at $8 \mathrm{Ser} / \mathrm{Thr}$ phospho-sites, including 4 serine residues in the C-terminal autoinhibitory domain. Phosphorylation of the autoinhibitory domain was originally proposed to trigger a more relaxed conformation of the protein allowing its phosphorylation at T389 by mTORC1 leading to S6K activation (Dennis et al., 1998). Thus, the blockade of canonical mTORC1/S6K signaling by the mTORC1 inhibitor rapamycin suppresses both basal and stimuli-induced rpS6 phosphorylation in various brain areas (Kelleher et al., 2004; Takei et al., 2004; Cota et al., 2006; Antion et al., 2008a; Gobert et al., 2008; Géranton et al., 2009; Santini et al., 2009; Zeng et al., 2009; Huang et al., 2010; Cao et al., 2011; Troca-Marín et al., 2011; Wu et al., 2011; Bailey et al., 2012; Bertran-Gonzalez et al., 2012; Meffre et al., 2012; Brewster et al., 2013; Macias et al., 2013; Bowling et al., 2014; Biever et al., 2015).

Although the activation of $\mathrm{S} 6 \mathrm{~K}$ and the subsequent phosphorylation of rpS6 are commonly used as a readout of mTORC1 activation, several evidences point out the existence of a synergistic crosstalk between mTORC1 and the extracellular signal-regulated kinase (ERK) signaling to control rpS6 phosphorylation. Thus, ERK can promote S6K activation by enhancing its phosphorylation at T421/S424 sites (Mukhopadhyay et al., 1992). When phosphorylated, these sites located in the autoinhibitory domain of the S6K1/2 are thought to prime the activation of $\mathrm{S} 6 \mathrm{~K}$, thereby facilitating the subsequent phosphorylation of the other sites of $\mathrm{S} 6 \mathrm{~K}$ by the upstream kinases (Dennis et al., 1998). Alternatively, ERK can also modulate the mTORC1/S6K cascade upstream of S6K. On the one hand, ERK-mediated inhibitory phosphorylation of Tuberous Sclerosis Complex 2 (TSC2) stimulates the Ras Homolog Enriched in Brain (Rheb) protein, which in turn activates mTORC1 (Roux and Blenis, 2004; Long et al., 2005; Ma et al., 2005). On the other hand, ERK can enhance mTORC1 activation through RSK-mediated phosphorylation of Raptor (Wettenhall et al., 1992). Examples of this synergistic interaction between ERK and mTORC1 in the regulation of rpS6 phosphorylation have been reported in several models and in various brain areas (Kelleher et al., 2004; Antion et al., 2008a; Gobert et al., 2008; Santini et al., 2009; Gangarossa et al., 2014) Interestingly, ERK can also regulate rpS6 phosphorylation at S235/236 through RSK independently of mTORC1/S6K signaling (Roux et al., 2007). Indeed, the increase in pS235/236-rpS6 promoted by tetraethylammonium in cultured cortical neurons is prevented by RSK3 inhibition (Gu et al., 2015). Finally, a recent study performed in hippocampal neurons demonstrated that the cdk5-dependent phosphorylation of S6K at S411 site is also 
critical in the regulation of S6K activation and the subsequent rpS6 phosphorylation at S235/236 sites (Lai et al., 2015).

\section{cAMP/PKA Pathway}

The enhanced rpS6 phosphorylation in the cerebral cortex following the administration of N6O-2' dibutyryl cAMP was one of the first demonstrations that cAMP could modulate in vivo the state of phosphorylation of rpS6 (Roberts and Morelos, 1979). Despite this evidence, the contribution of the cAMP/PKA pathway in the regulation of rpS6 phosphorylation in the nervous system has been largely neglected. However, recent studies highlighted the importance of cAMP/PKA signaling in the regulation of rpS6 phosphorylation at S235/236 sites. Thus, the direct stimulation of the adenylate cyclase by forskolin increases pS235/236-rpS6 in the striatum and the hippocampus (Gobert et al., 2008; Biever et al., 2015) (Table 1). Similar results are obtained when the degradation of cAMP is prevented by the administration of papaverine, a potent inhibitor of type 10A phosphodiesterase (Biever et al., 2015). Although the demonstration that PKA directly catalyzes rpS6 phosphorylation in the brain is still lacking, several indirect evidences support its contribution in the control of pS235/236-rpS6 following cAMP elevation. Indeed, forskolin-induced $\mathrm{rpS} 6$ phosphorylation in striatal slices is reduced in the presence of a PKA inhibitor (Biever et al., 2015). Moreover, stimulation of PKA activity with the cAMP analog cBIMPS increases pS235/236-rpS6 in striatal culture (Valjent et al., 2011) (Table 1). Finally, the administration of pharmacological agents promoting PKA activation triggers
rpS6 phosphorylation in several brain areas (Gobert et al., 2008; Valjent et al., 2011; Knight et al., 2012; Bonito-Oliva et al., 2013; Rapanelli et al., 2014; Biever et al., 2015; Sutton and Caron, 2015).

Although PKA targets selectively S235/236 residues (Moore et al., 2009), recent evidences suggest that PKA also contributes indirectly to $\mathrm{rpS} 6$ phosphorylation through a protein phosphatase cascade. This mechanism has been particularly well-studied in the striatum, where the inhibition of PP-1, controlled by the PKA-dependent phosphorylation of dopamine- and cAMP-regulated phosphoprotein, $\mathrm{Mr}$ 32,000 (DARPP-32) at T34 (Hemmings et al., 1984; Greengard, 2001), promotes pS235/236-rpS6 induced by d-amphetamine or haloperidol (Valjent et al., 2011; Bonito-Oliva et al., 2013; Biever et al., 2015). This mechanism also contributes to the regulation of rpS6 phosphorylation at S240/244 sites (Bonito-Oliva et al., 2013). These findings highlight the importance of PKA/DARPP32/PP-1 signaling in the regulation of $\mathrm{rpS} 6$ phosphorylation in the striatum and raise the intriguing hypothesis that similar mechanisms could take place in other brain areas.

\section{STIMULI MODULATING rpS6 PHOSPHORYLATION IN THE BRAIN}

Recently an increasing number of studies have used rpS6 phosphorylation as a marker for neuronal activation in the context of synaptic plasticity or in response to variety of therapeutic agents in physiological and pathophysiological contexts.

TABLE 1 | Pharmacological stimuli modulating rpS6 phosphorylation ex vivo.

\begin{tabular}{|c|c|c|c|c|c|}
\hline Brain areas & Model & Treatment & S235/236 & S240/244 & References \\
\hline \multicolumn{6}{|c|}{ WHOLE BRAIN } \\
\hline & Culture & Insulin & $\uparrow(N S)$ & $\uparrow(N S)$ & Heidenreich and Toledo, 1989 \\
\hline \multicolumn{6}{|c|}{ HIPPOCAMPUS } \\
\hline & Culture & BDNF & $\uparrow$ & ND & Kelleher et al., 2004; Troca-Marín et al., 2011 \\
\hline & & Bicuculline & $\uparrow$ & ND & Kelleher et al., 2004 \\
\hline & Slice & DHPG & $\uparrow$ & $\uparrow$ & Antion et al., $2008 \mathrm{a}$ \\
\hline & & Forskolin & $\uparrow$ & ND & Gobert et al., 2008 \\
\hline \multicolumn{6}{|l|}{ STRIATUM } \\
\hline & Culture & cBIMPS & $\uparrow$ & ND & Valjent et al., 2011 \\
\hline & & Haloperidol & ND & $\uparrow$ & Bowling et al., 2014 \\
\hline & Slice & Forskolin & $\uparrow$ & ND & Biever et al., 2015 \\
\hline & & 6-OHDA/SKF81297 & $\uparrow$ & $\uparrow$ & Santini et al., 2009 \\
\hline \multicolumn{6}{|l|}{ CORTEX } \\
\hline & Synaptoneurosomes & BDNF & ND & $\uparrow$ & Takei et al., 2004 \\
\hline & Culture & Leucine & ND & $\uparrow$ & Ishizuka et al., 2008 \\
\hline & & Bicuculline/glycine & $\uparrow$ & ND & Lai et al., 2012 \\
\hline & & Tetraethylammonium & $\uparrow$ & ND & Gu et al., 2015 \\
\hline & & BDNF & ND & $\uparrow$ & Lenz and Avruch, 2005 \\
\hline & & GNA & ND & $\uparrow$ & Lenz and Avruch, 2005 \\
\hline & & Glutamate/NMDA & ND & $\downarrow$ & Lenz and Avruch, 2005 \\
\hline & & Bicuculline/4-AP & ND & $\uparrow$ & Lenz and Avruch, 2005 \\
\hline
\end{tabular}

NS, not specified; ND, not determined; GNA, Glutamate + NMDA followed 5 s later by the NMDA antagonist APV; 4-AP, 4-aminopyridine. 
TABLE 2 | Pharmacological stimuli modulating rpS6 phosphorylation in vivo.

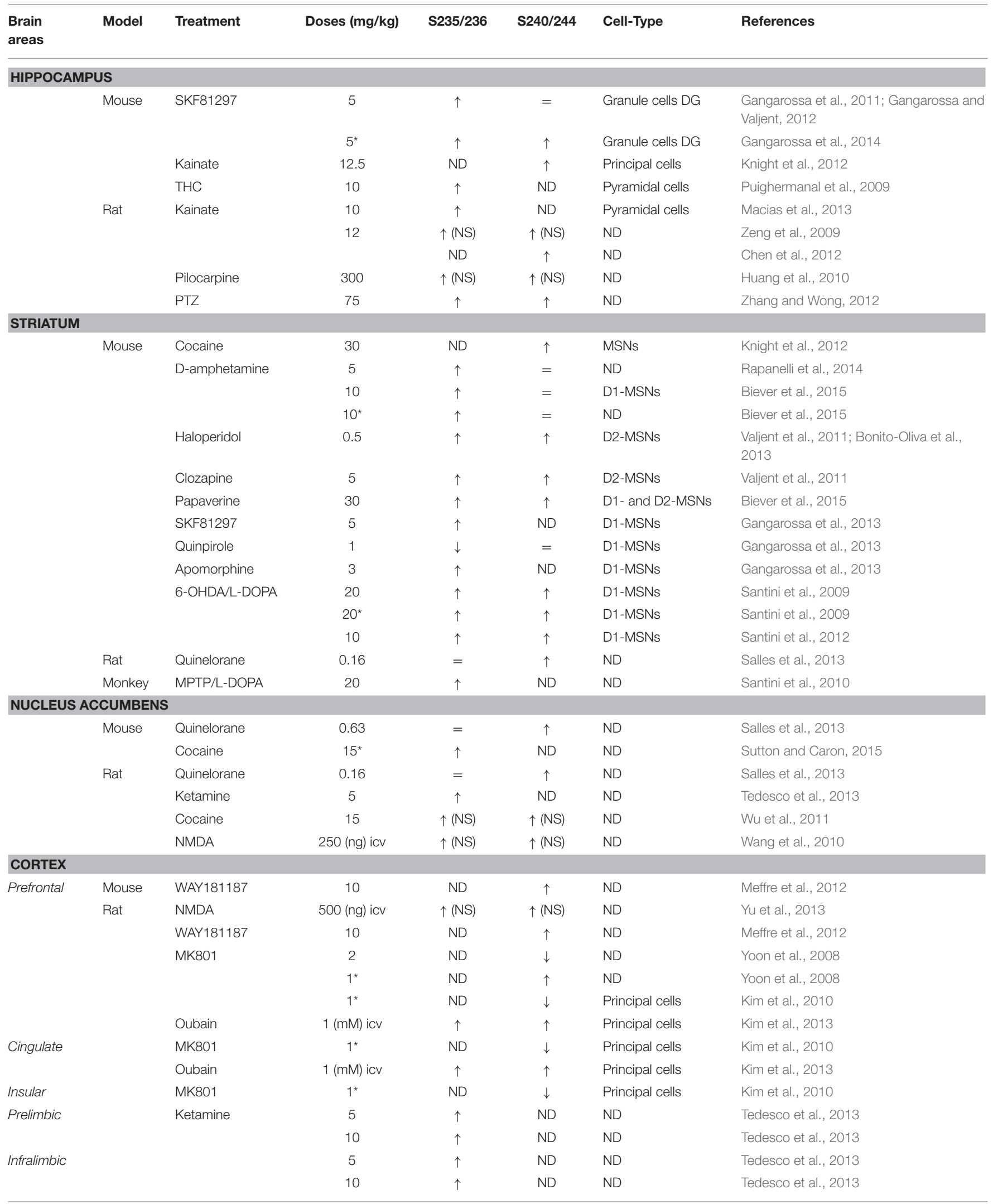


TABLE 2 | Continued

\begin{tabular}{|c|c|c|c|c|c|c|c|}
\hline $\begin{array}{l}\text { Brain } \\
\text { areas }\end{array}$ & Model & Treatment & Doses (mg/kg) & $\mathrm{S} 235 / 236$ & S240/244 & Cell-Type & References \\
\hline \multicolumn{2}{|l|}{ Somatosensory } & Kainate & 10 & $\uparrow$ & ND & pyramidal cells & Macias et al., 2013 \\
\hline \multicolumn{2}{|l|}{ Piriform } & & & $\uparrow$ & ND & ND & Macias et al., 2013 \\
\hline \multirow[t]{8}{*}{ NS } & & & 12 & ND & $\uparrow$ & ND & Chen et al., 2012 \\
\hline & & & & $\uparrow(\mathrm{NS})$ & $\uparrow(\mathrm{NS})$ & ND & Zeng et al., 2009 \\
\hline & & Pilocarpine & 300 & $\uparrow(\mathrm{NS})$ & $\uparrow(\mathrm{NS})$ & ND & Huang et al., 2010 \\
\hline & & PTZ & 75 & $\uparrow$ & $\uparrow$ & ND & Zhang and Wong, 2012 \\
\hline & & Cocaine & 15 & $\uparrow(\mathrm{NS})$ & $\uparrow(\mathrm{NS})$ & ND & Wu et al., 2011 \\
\hline & & MK801 & 0.5 & $\downarrow$ & $\downarrow$ & ND & Kim et al., 2010 \\
\hline & & & 1 & $\downarrow$ & $\downarrow$ & ND & Kim et al., 2010 \\
\hline & & L-phenylalanine & $2(\mathrm{mg} / \mathrm{g})$ & $\downarrow$ (NS) & $\downarrow$ (NS) & ND & Roberts and Morelos, 1979 \\
\hline \multicolumn{8}{|c|}{ VENTRAL TEGMENTAL AREA } \\
\hline & Mouse & Morphine & 25 (pellet)* $^{\star}$ & $\uparrow(N S)$ & $\uparrow(\mathrm{NS})$ & $\mathrm{TH}+$ cells & Mazei-Robison et al., 2011 \\
\hline & Rat & Cocaine & 15 & $\uparrow(\mathrm{NS})$ & $\uparrow(\mathrm{NS})$ & ND & Wu et al., 2011 \\
\hline \multicolumn{8}{|l|}{ AMYGDALA } \\
\hline Basolateral & Rat & Ketamine & 10 & $\uparrow$ & ND & ND & Tedesco et al., 2013 \\
\hline NS & & Kainate & 10 & $\uparrow$ & ND & ND & Macias et al., 2013 \\
\hline \multicolumn{8}{|c|}{ HYPOTHALAMUS } \\
\hline \multirow[t]{6}{*}{ Arcuate } & Mouse & Olanzapine & 20 & $\uparrow$ & ND & ND & Knight et al., 2012 \\
\hline & & Ghrelin & $66(\mathrm{mg})$ & $\uparrow$ & $\uparrow$ & $\mathrm{NPY}+$ cells & Knight et al., 2012 \\
\hline & & & $6(\mathrm{mg}) \mathrm{icv}$ & ND & $\uparrow$ & ND & Villanueva et al., 2009 \\
\hline & & Leptin & 5 (mg) icv & ND & $\uparrow$ & ND & Gong et al., 2007 \\
\hline & & Insulin & $300(\mathrm{mU} / \mathrm{ml})$ icv & ND & $\uparrow$ & ND & Villanueva et al., 2009 \\
\hline & & & $400(\mathrm{mU} / \mathrm{ml})$ & ND & $\uparrow$ & ND & Villanueva et al., 2009 \\
\hline \multicolumn{2}{|l|}{ Ventromedial } & & $300(\mathrm{mU} / \mathrm{ml})$ icv & ND & $\uparrow$ & ND & Villanueva et al., 2009 \\
\hline \multirow[t]{2}{*}{ Paraventricular } & & Clozapine & 10 & $\uparrow$ & ND & ND & Knight et al., 2012 \\
\hline & Rat & Leptin & $10(\mathrm{mg})$ icv & ND & $\uparrow$ & ND & Cota et al., 2006, 2008 \\
\hline \multirow[t]{3}{*}{ NS } & & CNTFAx15 & $1.5(\mathrm{mg}) \mathrm{icv}$ & ND & $\uparrow$ & ND & Cota et al., 2008 \\
\hline & & C75 & 30 (mg) icv & ND & $\uparrow$ & ND & Proulx et al., 2008 \\
\hline & & Cerulenin & 90 (mg) icv & ND & $\uparrow$ & ND & Proulx et al., 2008 \\
\hline
\end{tabular}

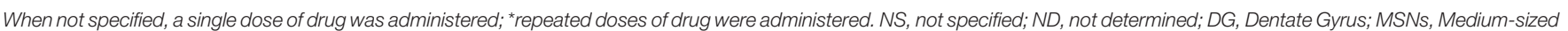
Spiny Neurons; THC, tetrahydrocannabinol; PTZ, Pentylenetetrazol; 6-OHDA, 6-hydroxydopamine; L-DOPA, levodopa; MPTP, 1-methyl-4-phenyl-1,2,3,6-tetrahydropyridine.

\section{Synaptic Plasticity}

Increased rpS6 phosphorylation during synaptic plasticity was reported for the first time by Klann and colleagues in 1991 using a synthetic peptide of rpS6 containing the residues 222249. Since then, enhanced rpS6 phosphorylation has been observed in several electrical or chemical models of synaptic plasticity. Thus, pS235/236-rpS6 increases in the CA1 subfield of the hippocampus during long-term potentiation following high frequency stimulation (Antion et al., 2008b) or forskolin application (Kelleher et al., 2004; Antion et al., 2008b; Gobert et al., 2008). Similarly, mGluR-dependent long-term depression induced by application of the mGluR1 agonist [3,5-RS] dihydroxyphenylhydrazine (DHPG) is associated with marked increases in pS235/236- and pS240/244-rpS6 in hippocampal slices (Antion et al., 2008a). Interestingly, a recent study reported that the state of phosphorylation of rpS6 at S240/244 sites could be used to estimate the neuronal activity state of striatal cholinergic interneurons (Bertran-Gonzalez et al., 2012).

\section{Pharmacological Stimuli}

A large number of pharmacological stimuli have been described to promote rpS6 phosphorylation in neurons (Tables 1, 2). Indeed, several ex vivo studies performed in slices or neuronal cultures showed that rpS6 phosphorylation is enhanced by stimuli triggering multiple forms of neuronal activity (Table 1). In vivo, the phosphorylation of $\mathrm{rpS6}$ has been assessed following a single or repeated administration of a large variety of pharmacological agents in various brain areas (Table 2). Thus, proconvulsant drugs such as kainate, pilocarpine, pentylenetetrazol (PTZ), or the dopamine D1R agonist SKF81297 lead to a massive increase in pS235/236- and pS240/244-rpS6 in principal cells in the hippocampus and in various cortical areas (Table 2). Moreover, the administration of drugs of abuse (cocaine, $\mathrm{d}$-amphetamine, methamphetamine, morphine, and tetrahydrocannabinol) as well as antipsychotics (haloperidol, clozapine, and olanzapine) also regulates rpS6 phosphorylation at multiple sites in several brain areas including 
TABLE 3 | rpS6 phosphorylation regulation under physiological and pathophysiological conditions.

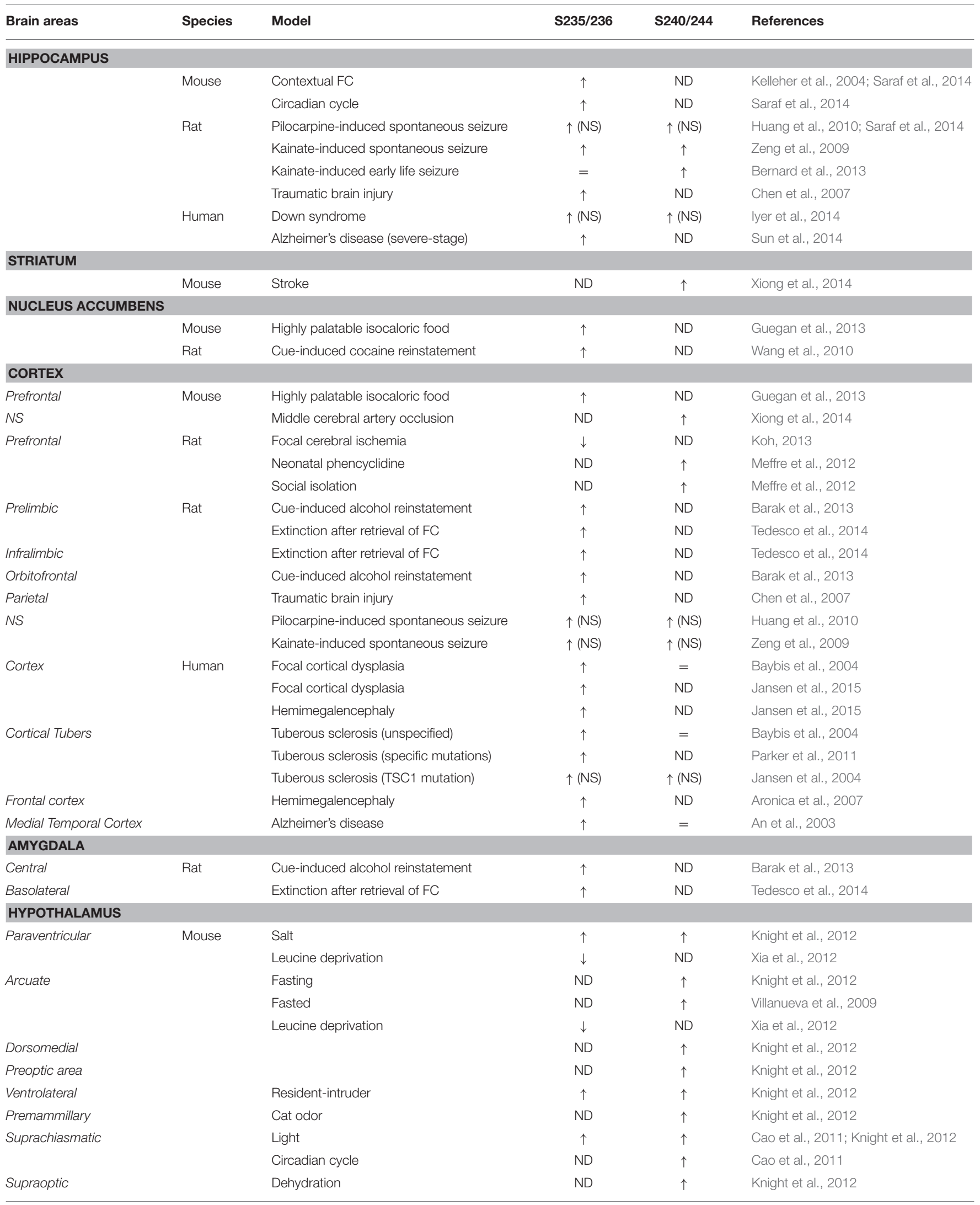


TABLE 3 | Continued

\begin{tabular}{|c|c|c|c|c|c|}
\hline Brain areas & Species & Model & $\mathrm{S} 235 / 236$ & S240/244 & References \\
\hline & & Salt & ND & $\uparrow$ & Knight et al., 2012 \\
\hline Arcuate & Rat & Fasted & ND & $\downarrow$ & Cota et al., 2006 \\
\hline \multicolumn{6}{|c|}{ PERIAQUEDUCTAL GRAY } \\
\hline & Mouse & Resident-intruder & $\uparrow$ & ND & Knight et al., 2012 \\
\hline \multicolumn{6}{|c|}{ SPINAL CORD } \\
\hline \multicolumn{6}{|c|}{ DORSAL ROOT GANGLIA } \\
\hline & Rat & Inflammatory pain (carrageenan) & $\uparrow$ & ND & Norsted Gregory et al., 2010 \\
\hline & & Neuropathic pain (SNI) & $\uparrow$ & ND & Géranton et al., 2009 \\
\hline \multirow[t]{2}{*}{ NS } & Human & Glioblastoma & $\uparrow$ & $=$ & Harter et al., 2015 \\
\hline & & SEGA & $\uparrow$ & ND & Chan et al., 2004 \\
\hline
\end{tabular}

NS, not specified; ND, not determined; FC, fear conditioning; SEGA, subependymal giant cell astrocytoma.

the striatum, the nucleus accumbens, the cortex, and the hippocampus (Table 2). Finally, several hormones involved in the regulation of energy balance enhance rpS6 phosphorylation in hypothalamic nuclei (Table 2).

\section{Physiological and Pathophysiological Conditions}

Since the pioneering report demonstrating that rpS6 phosphorylation was enhanced in the CA1 subfield of the hippocampus in mice trained to contextual fear conditioning (Kelleher et al., 2004), rpS6 phosphorylation has been used as a marker of neuronal and circuit activation following physiological conditions (Table 3). Thus, phospho-rpS6 levels oscillate in the hippocampus and the suprachiasmatic nucleus of the hypothalamus along the circadian cycle (Table 3). rpS6 phosphorylation is also strongly modulated in the amygdala and the hypothalamus when defensive behaviors (freezing, escape or attacks) are engaged or in the hypothalamus in response to nutritional perturbations (Table 3). Finally, altered rpS6 phosphorylation has been reported in rodents following spontaneous seizures and traumatic brain injury and in humans in several neurodevelopmental disorders including Down syndrome, Tuberous sclerosis, Autism, and Rett syndrome (Table 3).

\section{Genetic Mouse Models Displaying Altered rpS6 Phosphorylation}

Most of the full or conditional knockout mice for the key components of the mTORC1 pathway display altered rpS6 phosphorylation (Table 4). Interestingly, the vast majority of mutant mice in which dysregulation of rpS6 phosphorylation has been demonstrated correspond to mouse models for various neurological and neurodevelopmental disorders, including Tuberous sclerosis, Down syndrome, Rett syndrome, Angelman syndrome, and Fragile X syndrome, among others. Most of these pathologies share common features such as autism, intellectual disability, and epilepsy, which might be rescued by mTORC1 inhibitors under certain circumstances. The phosphorylation of rpS6 is also altered in neurodegenerative diseases such as Huntington disease and in mouse models of psychiatric disorders such as schizophrenia (Table 4). Other genetic mouse models showing hormonal perturbations as leptin deficiency also display altered rpS6 phosphorylation in the hypothalamus (Table 4).

\section{PHYSIOLOGICAL ROLE OF rpS6 PHOSPHORYLATION}

\section{Role in Overall mRNA Translation}

Despite the growing number of reports analyzing the phosphorylation of rpS6, its biological significance still remains controversial. One of the first hypotheses put forward suggested that rpS6 phosphorylation played a role in translation initiation. Thus, an early in vitro study reported a correlation between the phosphorylation of rpS6 and enhanced translation under certain experimental conditions (Thomas et al., 1982). Moreover, the 40S subunit with a highest proportion of phosphorylated rpS6 was preferentially found into polysomes compared to subpolysomal fractions (Duncan and McConkey, 1982). However, several studies rapidly called into question this hypothesis. Indeed, although localized at the mRNA/tRNA binding site junction between the small and large ribosomal subunits (Nygård and Nilsson, 1990), increased rpS6 phosphorylation is not sufficient to mobilize small ribosomal subunits into protein synthesis (Kruppa and Clemens, 1984; Tas and Martini, 1987). Finally, the generation of rpS6 knockin mice, in which the five phosphorylated serines were replaced by alanines, constituted a valuable tool to determine whether rpS6 phosphorylation and the protein synthesis were causally linked (Ruvinsky et al., 2005). Unexpectedly, protein synthesis is increased in mouse embryo fibroblasts (MEF) of phospho-deficient mice. Moreover, a similar (Ruvinsky et al., 2005) or even increased (Chauvin et al., 2014) proportion of ribosomes engaged in translation were found in the liver of rpS6 knockin mice. Together, these puzzling observations suggest a negative role of rpS6 phosphorylation on 
TABLE 4 | rpS6 phosphorylation in genetic mouse models.

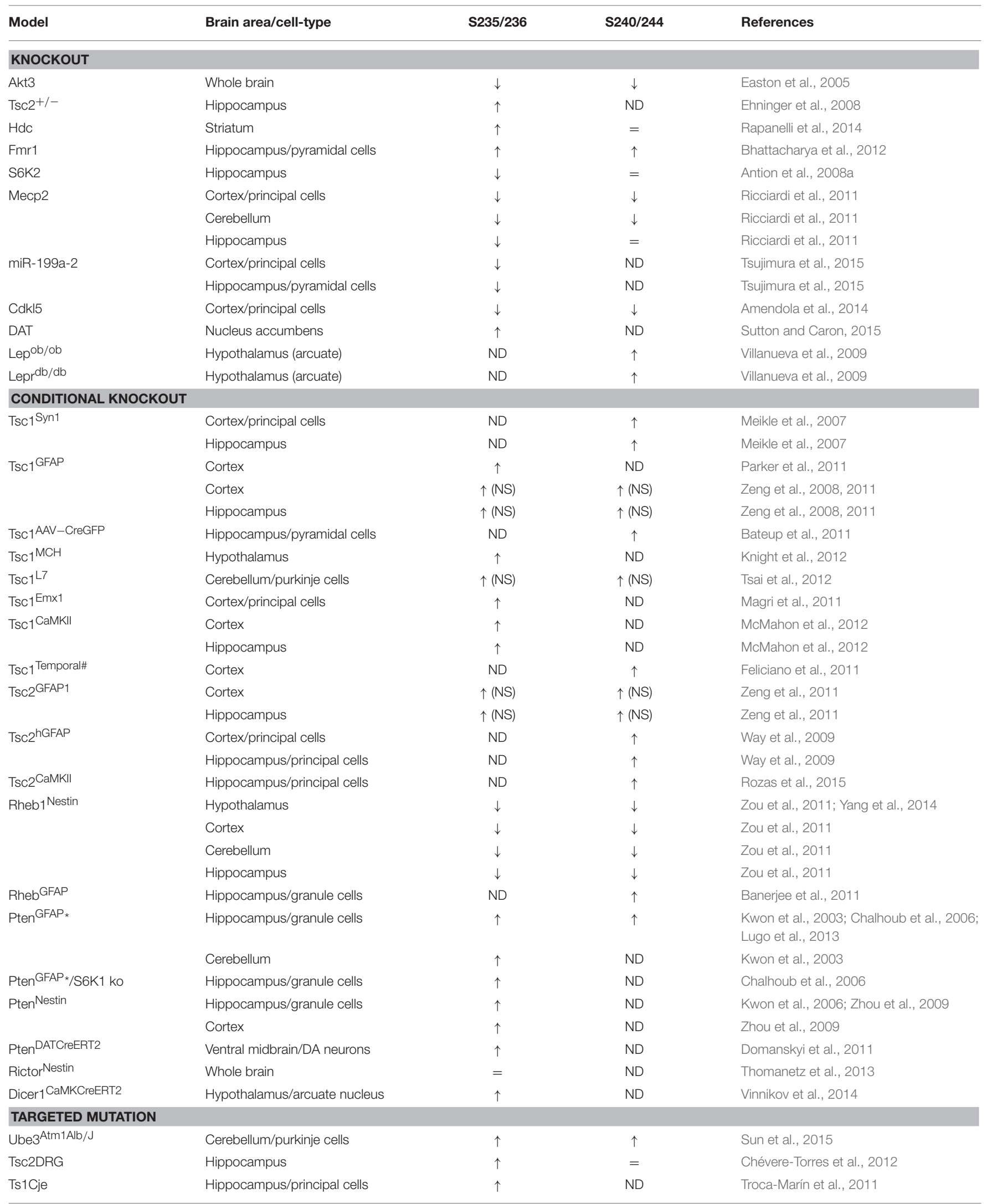




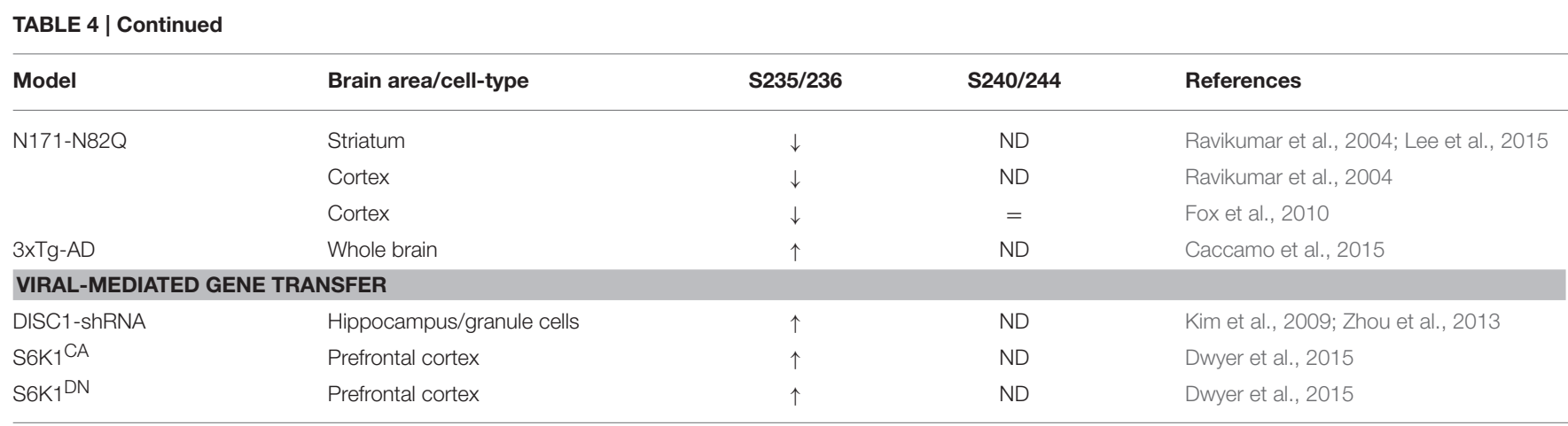

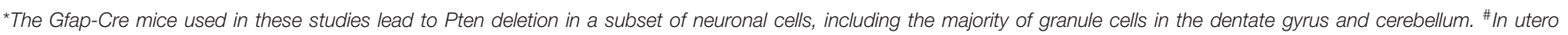
electroporation to express Cre recombinase and remove Tsc1 in Tsc1 floxed/mutant heterozygous embryos at E16. NS, not specified; ND, not determined; DA, dopaminergic.

global protein synthesis or the presence of feedback mechanisms taking place in this mouse model.

\section{Role in TOP mRNA Translation}

The phosphorylation of rpS6 through the mTORC1/S6K axis was believed for many years to exert an effect on the translation of a specific subset of mRNAs bearing a $5^{\prime}$ terminal oligopyrimidine tract (TOP). However, this long-lasting model has been challenged by subsequent studies showing that MEFs from the double mutant $\mathrm{S} 6 \mathrm{~K} 1 / 2$ as well as from the rpS6 knockin mouse lines exhibit normal TOP translation (Tang et al., 2001; Stolovich et al., 2002; Ruvinsky et al., 2005). Further work demonstrated that insulin-induced TOP translation requires the PI3K/TSC/Rheb/mTOR pathway but is independent of the S6K/rpS6 axis (Patursky-Polischuk et al., 2009).

Despite these evidences, the involvement of rpS6 phosphorylation in the control of translation in the nervous system is still controversial. Indeed, several findings in hippocampal neurons and slices correlated increased rpS6 phosphorylation with enhanced global and TOP-encoded protein synthesis following different forms of synaptic plasticity (Kelleher et al., 2004; Klann and Dever, 2004; Tsokas et al., 2005, 2007; Antion et al., 2008a,b) or in a mouse model of fragile X syndrome (Bhattacharya et al., 2012). By contrast, such correlations have not been observed in vivo in the striatum where the pharmacologically-induced rpS6 phosphorylation by damphetamine, haloperidol, or papaverine relies on the activation of the cAMP/PKA/DARPP-32 pathway (Biever et al., 2015). Interestingly, the direct binding of mRNA to the small ribosomal subunit decreases or increases after cAMP-dependent or cAMPindependent phosphorylation of rpS6, respectively (Burkhard and Traugh, 1983). Therefore, one cannot exclude that when an upstream signaling cascade other than PKA is engaged, for example mTORC1/S6K or ERK/RSK, rpS6 phosphorylation might have different physiological roles. Nevertheless, despite compelling studies indicating that rpS6 phosphorylation is dispensable for efficient global and TOP mRNA translation, the role of the phosphorylation in the translation of a specific subset of mRNAs remains to be fully addressed by high-throughput sequencing analyses of total and polysomal RNAs combined with proteomic approaches.

\section{Extratranslational Functions}

Another possibility is that rpS6 phosphorylation, within or outside the ribosome, exerts functions unrelated to mRNA translation, for example by interacting with other cellular proteins, which might become active or inactive upon the binding with rpS6. Indeed, co-immunoprecipitation studies suggest either a direct or indirect interaction of rpS6 with several extraribosomal proteins, including heat-shock protein 90 (Kim et al., 2006), alphavirus non-structural protein (Montgomery et al., 2006), DAPK (Schumacher et al., 2006), huntingtin (Culver et al., 2012), and mTOR complex 2 (mTORC2) (Yano et al., 2014). In the latter, rpS6 phosphorylation has been proposed to have a role in cardioprotective signaling by amplifying mTORC2-mediated Akt phosphorylation (Yano et al., 2014). In the mouse liver, Chauvin and colleagues recently uncovered the involvement of rpS6 phosphorylation in the control of the ribosome biogenesis ( $\mathrm{RiBi}$ ) transcriptional program by $\mathrm{S} 6 \mathrm{Ks}$ (Chauvin et al., 2014). This program regulates the expression of nucleolar proteins required for ribosomal RNA synthesis, cleavage, post-transcriptional modifications, ribosome assembly, and export (Lempiäinen and Shore, 2009). Whether all these translation-unrelated responses occur in the brain merits further study.

\section{Extraribosomal Functions}

Surprisingly, extraribosomal functions have been attributed to several ribosomal proteins (Wool, 1996; Warner and McIntosh, 2009). For instance, the ribosomal protein rpL13a, when phosphorylated, is released from the $60 \mathrm{~S}$ ribosomal subunit and acts as a silencer of targeted mRNAs (Mazumder et al., 2003). In this regard, few studies suggested an extraribosomal role of rpS6 phosphorylation (Kim et al., 2014; Son et al., 2015; Xiao et al., 2015). Recent work in the plant Arabidopsis Thaliana proposes a role of rpS6 in rRNA synthesis and rDNA transcription via its interaction with the histone deacetylase AtHD2B (Kim et al., 2014) and the histone chaperon AtNAP1 (Son et al., 2015), respectively, an effect that might be dependent on the phosphorylation state of rpS6. Finally, the ubiquitylation and proteasomal degradation of phosphorylated rpS6 following its subsequent interaction with PALL has been identified as a critical mechanism regulating efferocytosis in drosophila (Xiao et al., 
2015). To date, such extraribosomal functions of rpS6 in the nervous system have not been described.

\section{CONCLUDING REMARKS}

Since the pioneering studies performed four decades ago, many progresses have been made regarding the identification of signaling events leading to rpS6 phosphorylation. Although rpS6 phosphorylation is still considered as a readout of mTORC1/S6K activity, caution should be taken with this assumption since other intracellular cascades largely contribute to the regulation of rpS6 phosphorylation, as exemplified with the PKA/DARPP-32/PP-1 pathway in the striatum. One should also keep in mind that the different sites of phosphorylation can be regulated independently in various brain areas or different cell-types within a same brain region. Although rpS6 phosphorylation has been and will remain a valuable hallmark of neuronal activity, understanding

\section{REFERENCES}

Amendola, E., Zhan, Y., Mattucci, C., Castroflorio, E., Calcagno, E., Fuchs, C., et al. (2014). Mapping pathological phenotypes in a mouse model of CDKL5 disorder. PLoS ONE 9:e91613. doi: 10.1371/journal.pone.0091613

An, W. L., Cowburn, R. F., Li, L., Braak, H., Alafuzoff, I., Iqbal, K., et al. (2003). Up-regulation of phosphorylated/activated p70 S6 kinase and its relationship to neurofibrillary pathology in Alzheimer's disease. Am. J. Pathol. 163, 591-607. doi: $10.1016 / \mathrm{S} 0002-9440(10) 63687-5$

Antion, M. D., Hou, L., Wong, H., Hoeffer, C. A., and Klann, E. (2008a). mGluRdependent long-term depression is associated with increased phosphorylation of S6 and synthesis of elongation factor 1A but remains expressed in S6Kdeficient mice. Mol. Cell. Biol. 28, 2996-3007. doi: 10.1128/MCB.00201-08

Antion, M. D., Merhav, M., Hoeffer, C. A., Reis, G., Kozma, S. C., Thomas, G., et al. (2008b). Removal of S6K1 and S6K2 leads to divergent alterations in learning, memory, and synaptic plasticity. Learn. Mem. 15, 29-38. doi: 10.1101/lm.661908

Aronica, E., Boer, K., Baybis, M., Yu, J., and Crino, P. (2007). Co-expression of cyclin D1 and phosphorylated ribosomal S6 proteins in hemimegalencephaly. Acta Neuropathol. 114, 287-293. doi: 10.1007/s00401-007-0225-6

Bailey, J., Ma, D., and Szumlinski, K. K. (2012). Rapamycin attenuates the expression of cocaine-induced place preference and behavioral sensitization. Addict. Biol. 17, 248-258. doi: 10.1111/j.1369-1600.2010.00311.x

Bandi, H. R., Ferrari, S., Krieg, J., Meyer, H. E., and Thomas, G. (1993). Identification of $40 \mathrm{~S}$ ribosomal protein S6 phosphorylation sites in Swiss mouse 3T3 fibroblasts stimulated with serum. J. Biol. Chem. 268, 4530-4533.

Banerjee, S., Crouse, N. R., Emnett, R. J., Gianino, S. M., and Gutmann, D. H. (2011). Neurofibromatosis-1 regulates mTOR-mediated astrocyte growth and glioma formation in a TSC/Rheb-independent manner. Proc. Natl. Acad. Sci. U.S.A. 108, 15996-16001. doi: 10.1073/pnas.1019012108

Barak, S., Liu, F., Ben Hamida, S., Yowell, Q. V., Neasta, J., Kharazia, V., et al. (2013). Disruption of alcohol-related memories by mTORC1 inhibition prevents relapse. Nat. Neurosci. 16, 1111-1117. doi: 10.1038/nn.3439

Bateup, H. S., Takasaki, K. T., Saulnier, J. L., Denefrio, C. L., and Sabatini, B. L. (2011). Loss of Tscl in vivo impairs hippocampal mGluR-LTD and increases excitatory synaptic function. J. Neurosci. 31, 8862-8869. doi: 10.1523/JNEUROSCI.1617-11.2011

Baybis, M., Yu, J., Lee, A., Golden, J. A., Weiner, H., McKhann, G. II, et al. (2004). mTOR cascade activation distinguishes tubers from focal cortical dysplasia. Ann. Neurol. 56, 478-487. doi: 10.1002/ana.20211

Belandia, B., Brautigan, D., and Martín-Pérez, J. (1994). Attenuation of ribosomal protein S6 phosphatase activity in chicken embryo fibroblasts transformed by Rous sarcoma virus. Mol. Cell. Biol. 14, 200-206. doi: 10.1128/MCB. 14.1.200 its biological role in the brain is undoubtedly one of the major challenges of the coming years.

\section{AUTHOR CONTRIBUTIONS}

\author{
$\mathrm{AB}, \mathrm{EV}$, and $\mathrm{EP}$ wrote the manuscript.
}

\section{ACKNOWLEDGMENTS}

This work was supported by Inserm, Fondation pour la Recherche Médicale (EV), and a NARSAD Young Investigator Grant from the Brain and Behavior Research Foundation (EP). $A B$ is supported by the Fonds National de la Recherche, Luxembourg (Grant 3977033). EP is a recipient of Marie Curie Intra-European Fellowship IEF327648. The authors apologize to all colleagues whose work was not discussed in this Review.

Bernard, P. B., Castano, A. M., O’Leary, H., Simpson, K., Browning, M. D., and Benke, T. A. (2013). Phosphorylation of FMRP and alterations of FMRP complex underlie enhanced mLTD in adult rats triggered by early life seizures. Neurobiol. Dis. 59, 1-17. doi: 10.1016/j.nbd.2013.06.013

Bertran-Gonzalez, J., Chieng, B. C., Laurent, V., Valjent, E., and Balleine, B. W. (2012). Striatal cholinergic interneurons display activity-related phosphorylation of ribosomal protein S6. PLoS ONE 7:e53195. doi: 10.1371/journal.pone.0053195

Bhattacharya, A., Kaphzan, H., Alvarez-Dieppa, A. C., Murphy, J. P., Pierre, P., and Klann, E. (2012). Genetic removal of p70 S6 kinase 1 corrects molecular, synaptic, and behavioral phenotypes in fragile X syndrome mice. Neuron 76, 325-337. doi: 10.1016/j.neuron.2012.07.022

Biever, A., Puighermanal, E., Nishi, A., David, A., Panciatici, C., Longueville, S., et al. (2015). PKA-dependent phosphorylation of ribosomal protein S6 does not correlate with translation efficiency in striatonigral and striatopallidal medium-sized spiny neurons. J. Neurosci. 35, 4113-4130. doi: 10.1523/JNEUROSCI.3288-14.2015

Bonito-Oliva, A., Pallottino, S., Bertran-Gonzalez, J., Girault, J. A., Valjent, E., and Fisone, G. (2013). Haloperidol promotes mTORC1-dependent phosphorylation of ribosomal protein S6 via dopamine- and cAMP-regulated phosphoprotein of $32 \mathrm{kDa}$ and inhibition of protein phosphatase-1. Neuropharmacology 72, 197-203. doi: 10.1016/j.neuropharm.2013.04.043

Bowling, H., Zhang, G., Bhattacharya, A., Pérez-Cuesta, L. M., Deinhardt, K., Hoeffer, C. A., et al. (2014). Antipsychotics activate mTORC1-dependent translation to enhance neuronal morphological complexity. Sci. Signal. 7:ra4. doi: 10.1126/scisignal.2004331

Brewster, A. L., Lugo, J. N., Patil, V. V., Lee, W. L., Qian, Y., Vanegas, F., et al. (2013). Rapamycin reverses status epilepticus-induced memory deficits and dendritic damage. PLoS ONE 8:e57808. doi: 10.1371/journal.pone.0057808

Burkhard, S. J., and Traugh, J. A. (1983). Changes in ribosome function by cAMPdependent and cAMP-independent phosphorylation of ribosomal protein S6. J. Biol. Chem. 258, 14003-14008.

Caccamo, A., Branca, C., Talboom, J. S., Shaw, D. M., Turner, D., Ma, L., et al. (2015). Reducing ribosomal protein S6 kinase 1 expression improves spatial memory and synaptic plasticity in a mouse model of Alzheimer's disease. J. Neurosci. 35, 14042-14056. doi: 10.1523/JNEUROSCI.278115.2015

Cao, R., Anderson, F. E., Jung, Y. J., Dziema, H., and Obrietan, K. (2011). Circadian regulation of mammalian target of rapamycin signaling in the mouse suprachiasmatic nucleus. Neuroscience 181, 79-88. doi: 10.1016/j.neuroscience.2011.03.005

Chalhoub, N., Kozma, S. C., and Baker, S. J. (2006). S6k1 is not required for Pten-deficient neuronal hypertrophy. Brain Res. 1100, 32-41. doi: 10.1016/j.brainres.2006.05.013 
Chan, J. A., Zhang, H., Roberts, P. S., Jozwiak, S., Wieslawa, G., Lewin-Kowalik, J., et al. (2004). Pathogenesis of tuberous sclerosis subependymal giant cell astrocytomas: biallelic inactivation of TSC1 or TSC2 leads to mTOR activation. J. Neuropathol. Exp. Neurol. 63, 1236-1242.

Chauvin, C., Koka, V., Nouschi, A., Mieulet, V., Hoareau-Aveilla, C., Dreazen, A., et al. (2014). Ribosomal protein S6 kinase activity controls the ribosome biogenesis transcriptional program. Oncogene 33, 474-483. doi: 10.1038/onc.2012.606

Chen, L., Hu, L., Dong, J. Y., Ye, Q., Hua, N., Wong, M., et al. (2012). Rapamycin has paradoxical effects on S6 phosphorylation in rats with and without seizures. Epilepsia 53, 2026-2033. doi: 10.1111/epi.12013

Chen, S., Atkins, C. M., Liu, C. L., Alonso, O. F., Dietrich, W. D., and Hu, B. R. (2007). Alterations in mammalian target of rapamycin signaling pathways after traumatic brain injury. J. Cereb. Blood Flow Metab. 27, 939-949. doi: 10.1038/ sj.jcbfm. 9600393

Chévere-Torres, I., Kaphzan, H., Bhattacharya, A., Kang, A., Maki, J. M., Gambello, M. J., et al. (2012). Metabotropic glutamate receptor-dependent long-term depression is impaired due to elevated ERK signaling in the DeltaRG mouse model of tuberous sclerosis complex. Neurobiol. Dis. 45, 1101-1110. doi: 10.1016/j.nbd.2011.12.028

Cota, D., Matter, E. K., Woods, S. C., and Seeley, R. J. (2008). The role of hypothalamic mammalian target of rapamycin complex 1 signaling in dietinduced obesity. J. Neurosci. 28, 7202-7208. doi: 10.1523/JNEUROSCI.138908.2008

Cota, D., Proulx, K., Smith, K. A., Kozma, S. C., Thomas, G., Woods, S. C., et al. (2006). Hypothalamic mTOR signaling regulates food intake. Science 312, 927-930. doi: 10.1126/science.1124147

Culver, B. P., Savas, J. N., Park, S. K., Choi, J. H., Zheng, S., Zeitlin, S. O., et al. (2012). Proteomic analysis of wild-type and mutant huntingtinassociated proteins in mouse brains identifies unique interactions and involvement in protein synthesis. J. Biol. Chem. 287, 21599-21614. doi: 10.1074/jbc.M112.359307

Dennis, P. B., Pullen, N., Pearson, R. B., Kozma, S. C., and Thomas, G. (1998). Phosphorylation sites in the autoinhibitory domain participate in p70(s6k) activation loop phosphorylation. J. Biol. Chem. 273, 14845-14852. doi: $10.1074 /$ jbc. 273.24 .14845

Domanskyi, A., Geissler, C., Vinnikov, I. A., Alter, H., Schober, A., Vogt, M. A., et al. (2011). Pten ablation in adult dopaminergic neurons is neuroprotective in Parkinson's disease models. FASEB J. 25, 2898-2910. doi: 10.1096/fj.11-181958

Duncan, R., and McConkey, E. H. (1982). Rapid alterations in initiation rate and recruitment of inactive RNA are temporally correlated with S6 phosphorylation. Eur. J. Biochem. 123, 539-544. doi: 10.1111/j.14321033.1982.tb06565.x

Dwyer, J. M., Maldonado-Avilés, J. G., Lepack, A. E., Dileone, R. J., and Duman, R. S. (2015). Ribosomal protein S6 kinase 1 signaling in prefrontal cortex controls depressive behavior. Proc. Natl. Acad. Sci. U.S.A. 112, 6188-6193. doi: 10.1073/pnas.1505289112

Easton, R. M., Cho, H., Roovers, K., Shineman, D. W., Mizrahi, M., Forman, M. S., et al. (2005). Role for Akt3/protein kinase Bgamma in attainment of normal brain size. Mol. Cell. Biol. 25, 1869-1878. doi: 10.1128/MCB.25.5.18691878.2005

Ehninger, D., Han, S., Shilyansky, C., Zhou, Y., Li, W., Kwiatkowski, D. J., et al. (2008). Reversal of learning deficits in a Tsc2+/- mouse model of tuberous sclerosis. Nat. Med. 14, 843-848. doi: 10.1038/nm1788

Feliciano, D. M., Su, T., Lopez, J., Platel, J. C., and Bordey, A. (2011). Single-cell Tsc1 knockout during corticogenesis generates tuber-like lesions and reduces seizure threshold in mice. J. Clin. Invest. 121, 1596-1607. doi: 10.1172/JCI44909

Ferrari, S., Bandi, H. R., Hofsteenge, J., Bussian, B. M., and Thomas, G. (1991). Mitogen-activated 70K S6 kinase. Identification of in vitro $40 \mathrm{~S}$ ribosomal S6 phosphorylation sites. J. Biol. Chem. 266, 22770-22775.

Fox, J. H., Connor, T., Chopra, V., Dorsey, K., Kama, J. A., Bleckmann, D., et al. (2010). The mTOR kinase inhibitor Everolimus decreases S6 kinase phosphorylation but fails to reduce mutant huntingtin levels in brain and is not neuroprotective in the R6/2 mouse model of Huntington's disease. Mol. Neurodegener. 5, 26. doi: 10.1186/1750-1326-5-26

Gangarossa, G., Ceolin, L., Paucard, A., Lerner-Natoli, M., Perroy, J., Fagni, L., et al. (2014). Repeated stimulation of dopamine D1-like receptor and hyperactivation of mTOR signaling lead to generalized seizures, altered dentate gyrus plasticity, and memory deficits. Hippocampus 24, 1466-1481. doi: 10.1002/hipo.22327

Gangarossa, G., Di Benedetto, M., O’Sullivan, G. J., Dunleavy, M., Alcacer, C., Bonito-Oliva, A., et al. (2011). Convulsant doses of a dopamine D1 receptor agonist result in Erk-dependent increases in Zif268 and Arc/Arg3.1 expression in mouse dentate gyrus. PLoS ONE 6:e19415. doi: 10.1371/journal.pone.0019415

Gangarossa, G., Perroy, J., and Valjent, E. (2013). Combinatorial topography and cell-type specific regulation of the ERK pathway by dopaminergic agonists in the mouse striatum. Brain Struct. Funct. 218, 405-419. doi: 10.1007/s00429012-0405-6

Gangarossa, G., and Valjent, E. (2012). Regulation of the ERK pathway in the dentate gyrus by in vivo dopamine D1 receptor stimulation requires glutamatergic transmission. Neuropharmacology 63, 1107-1117. doi: 10.1016/j.neuropharm.2012.06.062

Géranton, S. M., Jiménez-Díaz, L., Torsney, C., Tochiki, K. K., Stuart, S. A., Leith J. L., et al. (2009). A rapamycin-sensitive signaling pathway is essential for the full expression of persistent pain states. J. Neurosci. 29, 15017-15027. doi: 10.1523/JNEUROSCI.3451-09.2009

Gobert, D., Topolnik, L., Azzi, M., Huang, L., Badeaux, F., Desgroseillers, L., et al. (2008). Forskolin induction of late-LTP and up-regulation of 5' TOP mRNAs translation via mTOR, ERK, and PI3K in hippocampal pyramidal cells. J. Neurochem. 106, 1160-1174. doi: 10.1111/j.1471-4159.2008. 05470.x

Gong, Y., Ishida-Takahashi, R., Villanueva, E. C., Fingar, D. C., Münzberg, H., and Myers, M. G. Jr. (2007). The long form of the leptin receptor regulates STAT5 and ribosomal protein S6 via alternate mechanisms. J. Biol. Chem. 282, 31019-31027. doi: 10.1074/jbc.M702838200

Greengard, P. (2001). The neurobiology of dopamine signaling. Biosci. Rep. 21, 247-269. doi: 10.1023/A:1013205230142

Gressner, A. M., and Wool, I. G. (1974). The phosphorylation of liver ribosomal proteins in vivo. Evidence that only a single small subunit protein (S6) is phosphorylated. J. Biol. Chem. 249, 6917-6925.

Gu, Q. H., Yu, D., Hu, Z., Liu, X., Yang, Y., Luo, Y., et al. (2015). miR-26a and miR-384-5p are required for LTP maintenance and spine enlargement. Nat. Commun. 6, 6789. doi: 10.1038/ncomms7789

Guegan, T., Cutando, L., Gangarossa, G., Santini, E., Fisone, G., Martinez, A., et al. (2013). Operant behavior to obtain palatable food modifies ERK activity in the brain reward circuit. Eur. Neuropsychopharmacol. 23, 240-252. doi: 10.1016/j.euroneuro.2012.04.009

Harter, P. N., Jennewein, L., Baumgarten, P., Ilina, E., Burger, M. C., Thiepold, A. L., et al. (2015). Immunohistochemical assessment of phosphorylated mTORC1-pathway proteins in human brain tumors. PLoS ONE 10:e0127123. doi: 10.1371/journal.pone.0127123

Heidenreich, K. A., and Toledo, S. P. (1989). Insulin receptors mediate growth effects in cultured fetal neurons. II. Activation of a protein kinase that phosphorylates ribosomal protein S6. Endocrinology 125, 1458-1463. doi: 10.1210/endo-125-3-1458

Hemmings, H. C. Jr., Nairn, A. C., Aswad, D. W., and Greengard, P. (1984). DARPP-32, a dopamine- and adenosine $3^{\prime}: 5^{\prime}$-monophosphateregulated phosphoprotein enriched in dopamine-innervated brain regions. II. Purification and characterization of the phosphoprotein from bovine caudate nucleus. J. Neurosci. 4, 99-110.

House, C., Wettenhall, R. E., and Kemp, B. E. (1987). The influence of basic residues on the substrate specificity of protein kinase C. J. Biol. Chem. 262, $772-777$.

Huang, X., Zhang, H., Yang, J., Wu, J., McMahon, J., Lin, Y., et al. (2010). Pharmacological inhibition of the mammalian target of rapamycin pathway suppresses acquired epilepsy. Neurobiol. Dis. 40, 193-199. doi: 10.1016/j.nbd.2010.05.024

Hutchinson, J. A., Shanware, N. P., Chang, H., and Tibbetts, R. S. (2011) Regulation of ribosomal protein S6 phosphorylation by casein kinase 1 and protein phosphatase 1. J. Biol. Chem. 286, 8688-8696. doi: 10.1074/jbc.M110.141754

Ishizuka, Y., Kakiya, N., Nawa, H., and Takei, N. (2008). Leucine induces phosphorylation and activation of p70S6K in cortical neurons via the system L amino acid transporter. J. Neurochem. 106, 934-942. doi: 10.1111/j.14714159.2008.05438.x 
Iyer, A. M., van Scheppingen, J., Milenkovic, I., Anink, J. J., Adle-Biassette, H., Kovacs, G. G., et al. (2014). mTOR Hyperactivation in down syndrome hippocampus appears early during development. J. Neuropathol. Exp. Neurol. 73, 671-683. doi: 10.1097/NEN.0000000000000083

Jansen, F. E., Notenboom, R. G., Nellist, M., Goedbloed, M. A., Halley, D. J., de Graan, P. N., et al. (2004). Differential localization of hamartin and tuberin and increased S6 phosphorylation in a tuber. Neurology 63, 1293-1295. doi: 10.1212/01.WNL.0000140702.08902.D7

Jansen, L. A., Mirzaa, G. M., Ishak, G. E., O’Roak, B. J., Hiatt, J. B., Roden, W. H., et al. (2015). PI3K/AKT pathway mutations cause a spectrum of brain malformations from megalencephaly to focal cortical dysplasia. Brain 138, 1613-1628. doi: 10.1093/brain/awv045

Kelleher, R. J. III, Govindarajan, A., Jung, H. Y., Kang, H., and Tonegawa, S. (2004). Translational control by MAPK signaling in long-term synaptic plasticity and memory. Cell 116, 467-479. doi: 10.1016/S0092-8674(04)00115-1

Kim, J. Y., Duan, X., Liu, C. Y., Jang, M. H., Guo, J. U., Pow-Anpongkul, N., et al. (2009). DISC1 regulates new neuron development in the adult brain via modulation of AKT-mTOR signaling through KIAA1212. Neuron 63, 761-773. doi: 10.1016/j.neuron.2009.08.008

Kim, S. H., Park, H. G., Kim, H. S., Ahn, Y. M., and Kim, Y. S. (2010). Effects of neonatal MK-801 treatment on p70S6K-S6/eIF4B signal pathways and protein translation in the frontal cortex of the developing rat brain. Int. J. Neuropsychopharmacol. 13, 1233-1246. doi: 10.1017/S1461145709991192

Kim, S. H., Yu, H. S., Park, H. G., Ha, K., Kim, Y. S., Shin, S. Y., et al. (2013). Intracerebroventricular administration of ouabain, a Na/K-ATPase inhibitor, activates mTOR signal pathways and protein translation in the rat frontal cortex. Prog. Neuropsychopharmacol. Biol. Psychiatry 45, 73-82. doi: 10.1016/j.pnpbp.2013.04.018

Kim, T. S., Jang, C. Y., Kim, H. D., Lee, J. Y., Ahn, B. Y., and Kim, J. (2006). Interaction of Hsp90 with ribosomal proteins protects from ubiquitination and proteasome-dependent degradation. Mol. Biol. Cell 17, 824-833. doi: 10.1091/mbc.E05-08-0713

Kim, Y. K., Kim, S., Shin, Y. J., Hur, Y. S., Kim, W. Y., Lee, M. S., et al. (2014). Ribosomal protein S6, a target of rapamycin, is involved in the regulation of rRNA genes by possible epigenetic changes in Arabidopsis. J. Biol. Chem. 289, 3901-3912. doi: 10.1074/jbc.M113.515015

Klann, E., and Dever, T. E. (2004). Biochemical mechanisms for translational regulation in synaptic plasticity. Nat. Rev. Neurosci. 5, 931-942. doi: 10.1038/nrn1557

Knight, Z. A., Tan, K., Birsoy, K., Schmidt, S., Garrison, J. L., Wysocki, R. W., et al. (2012). Molecular profiling of activated neurons by phosphorylated ribosome capture. Cell 151, 1126-1137. doi: 10.1016/j.cell.2012.10.039

Koh, P. O. (2013). Ferulic acid attenuates focal cerebral ischemia-induced decreases in p70S6 kinase and S6 phosphorylation. Neurosci. Lett. 555, 7-11. doi: 10.1016/j.neulet.2013.09.001

Kressler, D., Hurt, E., and Bassler, J. (2010). Driving ribosome assembly. Biochim. Biophys. Acta 1803, 673-683. doi: 10.1016/j.bbamcr.2009.10.009

Krieg, J., Hofsteenge, J., and Thomas, G. (1988). Identification of the 40 S ribosomal protein S6 phosphorylation sites induced by cycloheximide. J. Biol. Chem. 263, 11473-11477.

Kroczynska, B., Kaur, S., Katsoulidis, E., Majchrzak-Kita, B., Sassano, A., Kozma, S. C., et al. (2009). Interferon-dependent engagement of eukaryotic initiation factor $4 \mathrm{~B}$ via S6 kinase (S6K)- and ribosomal protein S6Kmediated signals. Mol. Cell. Biol. 29, 2865-2875. doi: 10.1128/MCB. 01537-08

Kruppa, J., and Clemens, M. J. (1984). Differential kinetics of changes in the state of phosphorylation of ribosomal protein $\mathrm{S} 6$ and in the rate of protein synthesis in MPC 11 cells during tonicity shifts. EMBO J. 3, 95-100.

Kwon, C. H., Luikart, B. W., Powell, C. M., Zhou, J., Matheny, S. A., Zhang, W., et al. (2006). Pten regulates neuronal arborization and social interaction in mice. Neuron 50, 377-388. doi: 10.1016/j.neuron.2006.03.023

Kwon, C. H., Zhu, X., Zhang, J., and Baker, S. J. (2003). mTor is required for hypertrophy of Pten-deficient neuronal soma in vivo. Proc. Natl. Acad. Sci. U.S.A. 100, 12923-12928. doi: 10.1073/pnas.2132711100

Lai, K. O., Liang, Z., Fei, E., Huang, H., and Ip, N. Y. (2015). Cyclin-dependent kinase 5 (Cdk5)-dependent phosphorylation of p70 ribosomal S6 kinase 1 (S6K) is required for dendritic spine morphogenesis. J. Biol. Chem. 290, 14637-14646. doi: 10.1074/jbc.M114.627117
Lai, K. O., Wong, A. S., Cheung, M. C., Xu, P., Liang, Z., Lok, K. C., et al. (2012). TrkB phosphorylation by Cdk5 is required for activity-dependent structural plasticity and spatial memory. Nat. Neurosci. 15, 1506-1515. doi: $10.1038 / \mathrm{nn} .3237$

Lastick, S. M., Nielsen, P. J., and McConkey, E. H. (1977). Phosphorylation of ribosomal protein S6 in suspension cultured HeLa cells. Mol. Gen. Genet. 152, 223-230. doi: 10.1007/BF00693074

Lee, J. H., Tecedor, L., Chen, Y. H., Monteys, A. M., Sowada, M. J., Thompson, L. M., et al. (2015). Reinstating aberrant mTORC1 activity in Huntington's disease mice improves disease phenotypes. Neuron 85, 303-315. doi: 10.1016/j.neuron.2014.12.019

Lempiäinen, H., and Shore, D. (2009). Growth control and ribosome biogenesis. Curr. Opin. Cell Biol. 21, 855-863. doi: 10.1016/j.ceb.2009.09.002

Lenz, G., and Avruch, J. (2005). Glutamatergic regulation of the p70S6 kinase in primary mouse neurons. J. Biol. Chem. 280, 38121-38124. doi: 10.1074/jbc.C500363200

Long, X., Lin, Y., Ortiz-Vega, S., Yonezawa, K., and Avruch, J. (2005). Rheb binds and regulates the mTOR kinase. Curr. Biol. 15, 702-713. doi: 10.1016/j.cub.2005.02.053

Lugo, J. N., Smith, G. D., Morrison, J. B., and White, J. (2013). Deletion of PTEN produces deficits in conditioned fear and increases fragile $\mathrm{X}$ mental retardation protein. Learn. Mem. 20, 670-673. doi: 10.1101/lm.032839.113

Ma, L., Chen, Z., Erdjument-Bromage, H., Tempst, P., and Pandolfi, P. P. (2005). Phosphorylation and functional inactivation of TSC2 by Erk implications for tuberous sclerosis and cancer pathogenesis. Cell 121, 179-193. doi: 10.1016/j.cell.2005.02.031

Macias, M., Blazejczyk, M., Kazmierska, P., Caban, B., Skalecka, A., Tarkowski, B., et al. (2013). Spatiotemporal characterization of mTOR kinase activity following kainic acid induced status epilepticus and analysis of rat brain response to chronic rapamycin treatment. PLOS ONE 8:e64455. doi: 10.1371/journal.pone. 0064455

Magri, L., Cambiaghi, M., Cominelli, M., Alfaro-Cervello, C., Cursi, M., Pala, M., et al. (2011). Sustained activation of mTOR pathway in embryonic neural stem cells leads to development of tuberous sclerosis complex-associated lesions. Cell Stem Cell 9, 447-462. doi: 10.1016/j.stem.2011.09.008

Mahoney, S. J., Dempsey, J. M., and Blenis, J. (2009). Cell signaling in protein synthesis ribosome biogenesis and translation initiation and elongation. Prog. Mol. Biol. Transl. Sci. 90, 53-107. doi: 10.1016/S1877-1173(09) 90002-3

Martin, K. A., Schalm, S. S., Romanelli, A., Keon, K. L., and Blenis, J. (2001). Ribosomal S6 kinase 2 inhibition by a potent C-terminal repressor domain is relieved by mitogen-activated protein-extracellular signal-regulated kinase kinase-regulated phosphorylation. J. Biol. Chem. 276, 7892-7898. doi: 10.1074/jbc.M009972200

Martin-Pérez, J., and Thomas, G. (1983). Ordered phosphorylation of 40S ribosomal protein S6 after serum stimulation of quiescent $3 \mathrm{~T} 3$ cells. Proc. Natl. Acad. Sci. U.S.A. 80, 926-930. doi: 10.1073/pnas.80.4.926

Mazei-Robison, M. S., Koo, J. W., Friedman, A. K., Lansink, C. S., Robison, A. J., Vinish, M., et al. (2011). Role for mTOR signaling and neuronal activity in morphine-induced adaptations in ventral tegmental area dopamine neurons. Neuron 72, 977-990. doi: 10.1016/j.neuron.2011.10.012

Mazumder, B., Sampath, P., Seshadri, V., Maitra, R. K., Dicorleto, P. E., and Fox, P. L. (2003). Regulated release of L13a from the 60 S ribosomal subunit as a mechanism of transcript-specific translational control. Cell 115, 187-198. doi: 10.1016/S0092-8674(03)00773-6

McMahon, J., Huang, X., Yang, J., Komatsu, M., Yue, Z., Qian, J., et al. (2012). Impaired autophagy in neurons after disinhibition of mammalian target of rapamycin and its contribution to epileptogenesis. J. Neurosci. 32, 15704-15714. doi: 10.1523/JNEUROSCI.2392-12.2012

Meffre, J., Chaumont-Dubel, S., Mannoury la Cour, C., Loiseau, F., Watson, D. J., Dekeyne, A., et al. (2012). 5-HT(6) receptor recruitment of mTOR as a mechanism for perturbed cognition in schizophrenia. EMBO Mol. Med. 4, 1043-1056. doi: 10.1002/emmm.201201410

Meikle, L., Talos, D. M., Onda, H., Pollizzi, K., Rotenberg, A., Sahin, M., et al. (2007). A mouse model of tuberous sclerosis: neuronal loss of Tscl causes dysplastic and ectopic neurons, reduced myelination, seizure activity, and limited survival. J. Neurosci. 27, 5546-5558. doi: 10.1523/JNEUROSCI.554006.2007 
Meyuhas, O. (2008). Physiological roles of ribosomal protein S6: one of its kind. Int. Rev. Cell Mol. Biol. 268, 1-37. doi: 10.1016/S1937-6448(08)00801-0

Meyuhas, O. (2015). Ribosomal protein S6 phosphorylation: four decades of research. Int. Rev. Cell Mol. Biol. 320, 41-73. doi: 10.1016/bs.ircmb.2015.07.006

Montgomery, S. A., Berglund, P., Beard, C. W., and Johnston, R. E. (2006). Ribosomal protein $\mathrm{S} 6$ associates with alphavirus nonstructural protein 2 and mediates expression from alphavirus messages. J. Virol. 80, 7729-7739. doi: 10.1128/JVI.00425-06

Moore, C. E., Xie, J., Gomez, E., and Herbert, T. P. (2009). Identification of cAMPdependent kinase as a third in vivo ribosomal protein S6 kinase in pancreatic beta-cells. J. Mol. Biol. 389, 480-494. doi: 10.1016/j.jmb.2009.04.020

Mukhopadhyay, N. K., Price, D. J., Kyriakis, J. M., Pelech, S., Sanghera, J., and Avruch, J. (1992). An array of insulin-activated, proline-directed serine/threonine protein kinases phosphorylate the p70 S6 kinase. J. Biol. Chem. 267, 3325-3335.

Norsted Gregory, E., Codeluppi, S., Gregory, J. A., Steinauer, J., and Svensson, C. I. (2010). Mammalian target of rapamycin in spinal cord neurons mediates hypersensitivity induced by peripheral inflammation. Neuroscience 169, 1392-1402. doi: 10.1016/j.neuroscience.2010.05.067

Nygård, O., and Nilsson, L. (1990). Translational dynamics. Interactions between the translational factors, tRNA and ribosomes during eukaryotic protein synthesis. Eur. J. Biochem. 191, 1-17. doi: 10.1111/j.1432-1033.1990.tb19087.x

Parker, W. E., Orlova, K. A., Heuer, G. G., Baybis, M., Aronica, E., Frost, M., et al. (2011). Enhanced epidermal growth factor, hepatocyte growth factor, and vascular endothelial growth factor expression in tuberous sclerosis complex. Am. J. Pathol. 178, 296-305. doi: 10.1016/j.ajpath.2010.11.031

Patursky-Polischuk, I., Stolovich-Rain, M., Hausner-Hanochi, M., Kasir, J., Cybulski, N., Avruch, J., et al. (2009). The TSC-mTOR pathway mediates translational activation of TOP mRNAs by insulin largely in a raptor- or rictor-independent manner. Mol. Cell. Biol. 29, 640-649. doi: 10.1128/MCB. 00980-08

Pende, M., Um, S. H., Mieulet, V., Sticker, M., Goss, V. L., Mestan, J., et al. (2004). S6K1(-/-)/S6K2(-/-) mice exhibit perinatal lethality and rapamycin-sensitive $5^{\prime}$-terminal oligopyrimidine mRNA translation and reveal a mitogen-activated protein kinase-dependent S6 kinase pathway. Mol. Cell. Biol. 24, 3112-3124. doi: 10.1128/MCB.24.8.3112-3124.2004

Proulx, K., Cota, D., Woods, S. C., and Seeley, R. J. (2008). Fatty acid synthase inhibitors modulate energy balance via mammalian target of rapamycin complex 1 signaling in the central nervous system. Diabetes 57, 3231-3238. doi: $10.2337 / \mathrm{db} 07-1690$

Puighermanal, E., Marsicano, G., Busquets-Garcia, A., Lutz, B., Maldonado, R., and Ozaita, A. (2009). Cannabinoid modulation of hippocampal long-term memory is mediated by mTOR signaling. Nat. Neurosci. 12, 1152-1158. doi: $10.1038 / \mathrm{nn} .2369$

Rapanelli, M., Frick, L. R., Pogorelov, V., Ota, K. T., Abbasi, E., Ohtsu, H., et al. (2014). Dysregulated intracellular signaling in the striatum in a pathophysiologically grounded model of Tourette syndrome. Eur. Neuropsychopharmacol. 24, 1896-1906. doi: 10.1016/j.euroneuro.2014.10.007

Ravikumar, B., Vacher, C., Berger, Z., Davies, J. E., Luo, S., Oroz, L. G., et al. (2004). Inhibition of mTOR induces autophagy and reduces toxicity of polyglutamine expansions in fly and mouse models of Huntington disease. Nat. Genet. 36, 585-595. doi: 10.1038/ng1362

Ricciardi, S., Boggio, E. M., Grosso, S., Lonetti, G., Forlani, G., Stefanelli, G., et al. (2011). Reduced AKT/mTOR signaling and protein synthesis dysregulation in a Rett syndrome animal model. Hum. Mol. Genet. 20, 1182-1196. doi: $10.1093 / \mathrm{hmg} / \mathrm{ddq} 563$

Roberts, S., and Morelos, B. S. (1979). Phosphorylation of multiple proteins of both ribosomal subunits in rat cerebral cortex in vivo. Effect of adenosine 3':5'-cyclic monophosphate. Biochem. J. 184, 233-244. doi: 10.1042/bj1840233

Roux, P. P., and Blenis, J. (2004). ERK and p38 MAPK-activated protein kinases: a family of protein kinases with diverse biological functions. Microbiol. Mol. Biol. Rev. 68, 320-344. doi: 10.1128/MMBR.68.2.320-344.2004

Roux, P. P., Shahbazian, D., Vu, H., Holz, M. K., Cohen, M. S., Taunton, J., et al. (2007). RAS/ERK signaling promotes site-specific ribosomal protein S6 phosphorylation via RSK and stimulates cap-dependent translation. J. Biol. Chem. 282, 14056-14064. doi: 10.1074/jbc.M700906200

Rozas, N. S., Redell, J. B., Mckenna, J. III, Moore, A. N., Gambello, M. J., and Dash, P. K. (2015). Prolonging the survival of Tsc2 conditional knockout mice by glutamine supplementation. Biochem. Biophys. Res. Commun. 457, 635-639. doi: 10.1016/j.bbrc.2015.01.039

Ruvinsky, I., Sharon, N., Lerer, T., Cohen, H., Stolovich-Rain, M., Nir, T., et al. (2005). Ribosomal protein S6 phosphorylation is a determinant of cell size and glucose homeostasis. Genes Dev. 19, 2199-2211. doi: 10.1101/gad.351605

Salles, M. J., Hervé, D., Rivet, J. M., Longueville, S., Millan, M. J., Girault, J. A., et al. (2013). Transient and rapid activation of Akt/GSK-3beta and mTORC1 signaling by $\mathrm{D} 3$ dopamine receptor stimulation in dorsal striatum and nucleus accumbens. J. Neurochem. 125, 532-544. doi: 10.1111/jnc.12206

Santini, E., Feyder, M., Gangarossa, G., Bateup, H. S., Greengard, P., and Fisone, G. (2012). Dopamine- and cAMP-regulated phosphoprotein of 32-kDa (DARPP-32)-dependent activation of extracellular signal-regulated kinase (ERK) and mammalian target of rapamycin complex 1 (mTORC1) signaling in experimental parkinsonism. J. Biol. Chem. 287, 27806-27812. doi: 10.1074/jbc.M112.388413

Santini, E., Heiman, M., Greengard, P., Valjent, E., and Fisone, G. (2009). Inhibition of mTOR signaling in Parkinson's disease prevents L-DOPA-induced dyskinesia. Sci. Signal. 2:ra36. doi: 10.1126/scisignal.2000308

Santini, E., Sgambato-Faure, V., Li, Q., Savasta, M., Dovero, S., Fisone, G., et al. (2010). Distinct changes in cAMP and extracellular signal-regulated protein kinase signalling in L-DOPA-induced dyskinesia. PLOS ONE 5:e12322. doi: 10.1371/journal.pone.0012322

Saraf, A., Luo, J., Morris, D. R., and Storm, D. R. (2014). Phosphorylation of eukaryotic translation initiation factor $4 \mathrm{E}$ and eukaryotic translation initiation factor 4E-binding protein (4EBP) and their upstream signaling components undergo diurnal oscillation in the mouse hippocampus: implications for memory persistence. J. Biol. Chem. 289, 20129-20138. doi: 10.1074/jbc.M114.552638

Schumacher, A. M., Velentza, A. V., Watterson, D. M., and Dresios, J. (2006). Death-associated protein kinase phosphorylates mammalian ribosomal protein S6 and reduces protein synthesis. Biochemistry 45, 13614-13621. doi: $10.1021 /$ bi060413y

Son, O., Kim, S., Shin, Y. J., Kim, W. Y., Koh, H. J., and Cheon, C. I. (2015). Identification of nucleosome assembly protein 1 (NAP1) as an interacting partner of plant ribosomal protein S6 (RPS6) and a positive regulator of rDNA transcription. Biochem. Biophys. Res. Commun. 465, 200-205. doi: 10.1016/j.bbrc.2015.07.150

Stolovich, M., Tang, H., Hornstein, E., Levy, G., Cohen, R., Bae, S. S., et al. (2002). Transduction of growth or mitogenic signals into translational activation of TOP mRNAs is fully reliant on the phosphatidylinositol 3-kinase-mediated pathway but requires neither S6K1 nor rpS6 phosphorylation. Mol. Cell. Biol. 22, 8101-8113. doi: 10.1128/MCB.22.23.8101-8113.2002

Sun, J., Liu, Y., Moreno, S., Baudry, M., and Bi, X. (2015). Imbalanced mechanistic target of rapamycin $\mathrm{C} 1$ and $\mathrm{C} 2$ activity in the cerebellum of Angelman syndrome mice impairs motor function. J. Neurosci. 35, 4706-4718. doi: 10.1523/JNEUROSCI.4276-14.2015

Sun, Y. X., Ji, X., Mao, X., Xie, L., Jia, J., Galvan, V., et al. (2014). Differential activation of mTOR complex 1 signaling in human brain with mild to severe Alzheimer's disease. J. Alzheimers Dis. 38, 437-444. doi: 10.3233/JAD-131124

Sutton, L. P., and Caron, M. G. (2015). Essential role of D1R in the regulation of mTOR complex1 signaling induced by cocaine. Neuropharmacology 99, 610-619. doi: 10.1016/j.neuropharm.2015.08.024

Takei, N., Inamura, N., Kawamura, M., Namba, H., Hara, K., Yonezawa, K., et al. (2004). Brain-derived neurotrophic factor induces mammalian target of rapamycin-dependent local activation of translation machinery and protein synthesis in neuronal dendrites. J. Neurosci. 24, 9760-9769. doi: 10.1523/JNEUROSCI.1427-04.2004

Tang, H., Hornstein, E., Stolovich, M., Levy, G., Livingstone, M., Templeton, D., et al. (2001). Amino acid-induced translation of TOP mRNAs is fully dependent on phosphatidylinositol 3-kinase-mediated signaling, is partially inhibited by rapamycin, and is independent of S6K1 and rpS6 phosphorylation. Mol. Cell. Biol. 21, 8671-8683. doi: 10.1128/MCB.21.24.8671-8683.2001

Tas, P. W., and Martini, O. H. (1987). Are highly phosphorylated 40-S subunits preferentially utilized during protein synthesis in a cell-free system from HeLa cells? Eur. J. Biochem. 163, 561-567. doi: 10.1111/j.1432-1033.1987.tb 10904.x

Tedesco, V., Ravagnani, C., Bertoglio, D., and Chiamulera, C. (2013). Acute ketamine-induced neuroplasticity: ribosomal protein S6 phosphorylation 
expression in drug addiction-related rat brain areas. Neuroreport 24, 388-393. doi: 10.1097/WNR.0b013e32836131ad

Tedesco, V., Roquet, R. F., DeMis, J., Chiamulera, C., and Monfils, M. H. (2014). Extinction, applied after retrieval of auditory fear memory, selectively increases zinc-finger protein 268 and phosphorylated ribosomal protein $\mathrm{S} 6$ expression in prefrontal cortex and lateral amygdala. Neurobiol. Learn. Mem. 115, 78-85. doi: 10.1016/j.nlm.2014.08.015

Thomanetz, V., Angliker, N., Cloëtta, D., Lustenberger, R. M., Schweighauser, M., Oliveri, F., et al. (2013). Ablation of the mTORC2 component rictor in brain or Purkinje cells affects size and neuron morphology. J. Cell Biol. 201, 293-308. doi: $10.1083 /$ jcb.201205030

Thomas, G., Martin-Pérez, J., Siegmann, M., and Otto, A. M. (1982). The effect of serum, EGF, PGF2 alpha and insulin on S6 phosphorylation and the initiation of protein and DNA synthesis. Cell 30, 235-242. doi: 10.1016/00928674(82)90029-0

Troca-Marín, J. A., Alves-Sampaio, A., and Montesinos, M. L. (2011). An increase in basal BDNF provokes hyperactivation of the Akt-mammalian target of rapamycin pathway and deregulation of local dendritic translation in a mouse model of Down's syndrome. J. Neurosci. 31, 9445-9455. doi: 10.1523/JNEUROSCI.0011-11.2011

Tsai, P. T., Hull, C., Chu, Y., Greene-Colozzi, E., Sadowski, A. R., Leech, J. M., et al. (2012). Autistic-like behaviour and cerebellar dysfunction in Purkinje cell Tsc1 mutant mice. Nature 488, 647-651. doi: 10.1038/nature11310

Tsokas, P., Grace, E. A., Chan, P., Ma, T., Sealfon, S. C., Iyengar, R., et al. (2005). Local protein synthesis mediates a rapid increase in dendritic elongation factor 1A after induction of late long-term potentiation. J. Neurosci. 25, 5833-5843. doi: 10.1523/JNEUROSCI.0599-05.2005

Tsokas, P., Ma, T., Iyengar, R., Landau, E. M., and Blitzer, R. D. (2007). Mitogenactivated protein kinase upregulates the dendritic translation machinery in long-term potentiation by controlling the mammalian target of rapamycin pathway. J. Neurosci. 27, 5885-5894. doi: 10.1523/JNEUROSCI.4548-06.2007

Tsujimura, K., Irie, K., Nakashima, H., Egashira, Y., Fukao, Y., Fujiwara, M., et al. (2015). miR-199a links MeCP2 with mTOR signaling and its dysregulation leads to rett syndrome phenotypes. Cell Rep. 12, 1887-1901. doi: 10.1016/j.celrep.2015.08.028

Valjent, E., Bertran-Gonzalez, J., Bowling, H., Lopez, S., Santini, E., Matamales, M., et al. (2011). Haloperidol regulates the state of phosphorylation of ribosomal protein S6 via activation of PKA and phosphorylation of DARPP-32. Neuropsychopharmacology 36, 2561-2570. doi: 10.1038/npp.2011.144

Villanueva, E. C., Münzberg, H., Cota, D., Leshan, R. L., Kopp, K., IshidaTakahashi, R., et al. (2009). Complex regulation of mammalian target of rapamycin complex 1 in the basomedial hypothalamus by leptin and nutritional status. Endocrinology 150, 4541-4551. doi: 10.1210/en.2009-0642

Vinnikov, I. A., Hajdukiewicz, K., Reymann, J., Beneke, J., Czajkowski, R., Roth, L. C., et al. (2014). Hypothalamic miR-103 protects from hyperphagic obesity in mice. J. Neurosci. 34, 10659-10674. doi: 10.1523/JNEUROSCI.4251-13.2014

Wang, X., Luo, Y. X., He, Y. Y., Li, F. Q., Shi, H. S., Xue, L. F., et al. (2010). Nucleus accumbens core mammalian target of rapamycin signaling pathway is critical for cue-induced reinstatement of cocaine seeking in rats. J. Neurosci. 30, 12632-12641. doi: 10.1523/JNEUROSCI.1264-10.2010

Warner, J. R., and McIntosh, K. B. (2009). How common are extraribosomal functions of ribosomal proteins? Mol. Cell 34, 3-11. doi: 10.1016/j.molcel.2009.03.006

Way, S. W., Mckenna, J. III, Mietzsch, U., Reith, R. M., Wu, H. C., and Gambello, M. J. (2009). Loss of Tsc2 in radial glia models the brain pathology of tuberous sclerosis complex in the mouse. Hum. Mol. Genet. 18, 1252-1265. doi: $10.1093 / \mathrm{hmg} / \mathrm{ddp} 025$

Wettenhall, R. E., Erikson, E., and Maller, J. L. (1992). Ordered multisite phosphorylation of Xenopus ribosomal protein S6 by S6 kinase II. J. Biol. Chem. 267, 9021-9027.

Wool, I. G. (1996). Extraribosomal functions of ribosomal proteins. Trends Biochem. Sci. 21, 164-165. doi: 10.1016/S0968-0004(96)20011-8

Wu, J., McCallum, S. E., Glick, S. D., and Huang, Y. (2011). Inhibition of the mammalian target of rapamycin pathway by rapamycin blocks cocaine-induced locomotor sensitization. Neuroscience 172, 104-109. doi: 10.1016/j.neuroscience.2010.10.041
Xia, T., Cheng, Y., Zhang, Q., Xiao, F., Liu, B., Chen, S., et al. (2012). S6K1 in the central nervous system regulates energy expenditure via MC4R/CRH pathways in response to deprivation of an essential amino acid. Diabetes 61, 2461-2471. doi: $10.2337 / \mathrm{db} 11-1278$

Xiao, H., Wang, H., Silva, E. A., Thompson, J., Guillou, A., Yates, J. R. Jr., et al. (2015). The Pallbearer E3 ligase promotes actin remodeling via RAC in efferocytosis by degrading the ribosomal protein S6. Dev. Cell 32, 19-30. doi: 10.1016/j.devcel.2014.11.015

Xiong, X., Xie, R., Zhang, H., Gu, L., Xie, W., Cheng, M., et al. (2014). PRAS40 plays a pivotal role in protecting against stroke by linking the Akt and mTOR pathways. Neurobiol. Dis. 66, 43-52. doi: 10.1016/j.nbd.2014.02.006

Xue, S., and Barna, M. (2012). Specialized ribosomes: a new frontier in gene regulation and organismal biology. Nat. Rev. Mol. Cell Biol. 13, 355-369. doi: $10.1038 / \mathrm{nrm} 3359$

Yang, W., Jiang, W., Luo, L., Bu, J., Pang, D., Wei, J., et al. (2014). Genetic deletion of Rheb1 in the brain reduces food intake and causes hypoglycemia with altered peripheral metabolism. Int. J. Mol. Sci. 15, 1499-1510. doi: 10.3390/ijms15011499

Yano, T., Ferlito, M., Aponte, A. M., Kuno, A., Miura, T., Murphy, E., et al. (2014). Pivotal role of mTORC2 and involvement of ribosomal protein S6 in cardioprotective signaling. Circ. Res. 114, 1268-1280. doi: 10.1161/ CIRCRESAHA.114.303562

Yoon, S. C., Seo, M. S., Kim, S. H., Jeon, W. J., Ahn, Y. M., Kang, U. G., et al. (2008). The effect of MK-801 on mTOR/p70S6K and translation-related proteins in rat frontal cortex. Neurosci. Lett. 434, 23-28. doi: 10.1016/j.neulet.2008. 01.020

Yu, J. J., Zhang, Y., Wang, Y., Wen, Z. Y., Liu, X. H., Qin, J., et al. (2013). Inhibition of calcineurin in the prefrontal cortex induced depressive-like behavior through mTOR signaling pathway. Psychopharmacology (Berl). 225, 361-372. doi: 10.1007/s00213-012-2823-9

Zeng, L. H., Rensing, N. R., and Wong, M. (2009). The mammalian target of rapamycin signaling pathway mediates epileptogenesis in a model of temporal lobe epilepsy. J. Neurosci. 29, 6964-6972. doi: 10.1523/JNEUROSCI.006609.2009

Zeng, L. H., Rensing, N. R., Zhang, B., Gutmann, D. H., Gambello, M. J., and Wong, M. (2011). Tsc2 gene inactivation causes a more severe epilepsy phenotype than Tscl inactivation in a mouse model of tuberous sclerosis complex. Hum. Mol. Genet. 20, 445-454. doi: 10.1093/hmg/ddq491

Zeng, L. H., Xu, L., Gutmann, D. H., and Wong, M. (2008). Rapamycin prevents epilepsy in a mouse model of tuberous sclerosis complex. Ann. Neurol. 63, 444-453. doi: 10.1002/ana.21331

Zhang, B., and Wong, M. (2012). Pentylenetetrazole-induced seizures cause acute, but not chronic, mTOR pathway activation in rat. Epilepsia 53, 506-511. doi: 10.1111/j.1528-1167.2011.03384.x

Zhou, J., Blundell, J., Ogawa, S., Kwon, C. H., Zhang, W., Sinton, C., et al. (2009). Pharmacological inhibition of mTORC1 suppresses anatomical, cellular, and behavioral abnormalities in neural-specific Pten knock-out mice. J. Neurosci. 29, 1773-1783. doi: 10.1523/JNEUROSCI.5685-08.2009

Zhou, M., Li, W., Huang, S., Song, J., Kim, J. Y., Tian, X., et al. (2013). mTOR Inhibition ameliorates cognitive and affective deficits caused by Discl knockdown in adult-born dentate granule neurons. Neuron 77, 647-654. doi: 10.1016/j.neuron.2012.12.033

Zou, J., Zhou, L., Du, X. X., Ji, Y., Xu, J., Tian, J., et al. (2011). Rheb1 is required for mTORC1 and myelination in postnatal brain development. Dev. Cell 20, 97-108. doi: 10.1016/j.devcel.2010.11.020

Conflict of Interest Statement: The authors declare that the research was conducted in the absence of any commercial or financial relationships that could be construed as a potential conflict of interest.

Copyright $\odot 2015$ Biever, Valjent and Puighermanal. This is an open-access article distributed under the terms of the Creative Commons Attribution License (CC BY). The use, distribution or reproduction in other forums is permitted, provided the original author(s) or licensor are credited and that the original publication in this journal is cited, in accordance with accepted academic practice. No use, distribution or reproduction is permitted which does not comply with these terms. 